\title{
Revisiting Teacher Working Group in Indonesia
}

\author{
Haholongan Simanjuntak ${ }^{1}$, Sahat Maruli ${ }^{2, *}$, Lisbeth Laora Silitonga ${ }^{3}$ \\ ${ }^{1}$ Faculty of Teacher Training and Education, Indonesia Open University, Indonesia \\ ${ }^{2}$ Center for Development and Empowerment of Teachers and Education Personnel (CDETEP) of Building and Electricity Sector, \\ Ministry of Education and Culture, Indonesia \\ ${ }^{3}$ Faculty of Nursing and Midwifery, Prima University of Indonesia, Indonesia
}

Received November 29, 2019; Revised January 14, 2020; Accepted February 25, 2020

Copyright $\bigcirc 2020$ by authors, all rights reserved. Authors agree that this article remains permanently open access under the terms of the Creative Commons Attribution License 4.0 International License

\begin{abstract}
This paper explores the issue of teacher change, professional learning communities and their impact on student achievement, and teacher working groups in the context of Indonesia. We use secondary data of teachers' competency test for the last two years. Then, we analyze the data and defend our opinions based on literature review. We explore Guskey's model of the process of teacher change and Clarke and Hollingsworth's interconnected model of teacher professional growth. Then, we discuss the effectiveness of PLCs that can lead to teacher professional learning, which in turn improve instructional practice and students' learning outcomes. This research identifies the weaknesses of teacher working groups activities in Indonesia and provides chances to improve it.
\end{abstract}

Keywords Teacher Change, Change Model, Teacher Learning, Professional Learning Communities, Student Achievement

\section{Introduction}

\subsection{History of Teacher Working Group in Indonesia - At Glance}

In 1993, the Ministry of Education and Culture introduced teacher working groups as local networking forums for teachers to communicate, consult, and share information and experiences to help their colleges to improve competencies based on their own ability. The teacher working groups are cluster-based and consists of teachers from neighbouring schools. Recently, as some schools become larger, the teacher working groups have expanded to include subject teachers in the same school.

At present, there are 1186 subject teacher working groups (or cluster) of Vocational School in 11 provinces under the supervision of CDETEP of Building and Electricity Sector. Its member can be from one or some regencies with the total number of members until 49 people. This year, The Ministry of Education and Culture is optimizing the role of clusters, many trainings will be done in the cluster.

\subsection{The Issue of Cluster Effectiveness}

Ragatz and Kesuma (2009, in [1]) reported that teachers in Indonesia find cluster very beneficial, but there are several constraints of its effectiveness:

a. lack of innovative program structures.

b. need for the intensive capacity building for facilitators.

c. need more fund.

d. need for regulation: credit for working group activities, effectiveness evaluation.

e. need for upgrading equipment and facilities.

Cluster activities are generally preparation of class administration such as curriculum and instructional material development, test item design. Some of the clusters is doing lesson study, classroom action research, workshops and structured blended workshops. Since the number of teacher clusters is large, only a small number are active at any one time.

\subsection{This Study}

The problem of teacher competency were revealed from the results of international measurements. PISA and TIMSS conducted periodically for three years show that there are no tendency to increase of student learning outcomes during the reforms. Even, the increase in pay of certified teacher led to no improvement in student learning outcomes [2].

We use secondary data of teacher's competency test for the last two years. Then, we analyze the data and defend 
our opinions based on literature review.

Reflecting on the international experience, the subject teacher working groups are similar to professional learning communities (PLCs). PLC is an important component to improve teacher competency in various countries. This study is an efforts to increase the effectiveness of the subject teacher working group through recommend PLC effectiveness studies to be implemented in Indonesia.

\subsection{Goal and Outline of This Report}

The main purpose of this paper is to review the process of teacher change and the effectiveness of PLCs in improving teacher capabilities. Then we compare the differences between the subject teacher working group and PLC, and discuss it.

This analysis is expected to inform policymakers and practitioners in Indonesia who are responsible for designing, planning, and implementing strong professional learning opportunities, instructional improvements, and ultimately improving student achievement.

Policymakers and practitioners in Indonesia can begin evaluating the needs of the PLC system so that teachers can learn and work well, and consider how teacher learning opportunities could be more effectively supported.

In the next section, we review the teacher change model and the elements of effective PLC initiatives, offering examples of specific studies and PLC models. Furthermore, we offer an overview of the broader conditions that support or inhibit an effective PLC. We conclude consideration for policies and practices in the context of education in Indonesia.

\section{Teacher Change and Learning in Cluster}

\subsection{Model of Teacher Change}

An effective and experience-based teacher change model [3] is a model proposed by Guskey. Significant changes in teacher beliefs and behaviors occur after the teacher sees an increase in student achievement [4], and not the other way around. Commitment to using new instructional approaches, new materials and curriculum, or change of teaching procedure carry out through the inquiry process where the teacher is actively engaged in practice and sees the desired change in learning outcomes[3].

Guskey's model elaborated by Clarke and Peter (1993 in [3]) to become a dynamic model of teacher professional growth. Changes occur in personal domains (teacher knowledge, beliefs and attitudes), practice domains (professional experimentation), consequent domains (student learning outcomes), and external domains (professional development/learning opportunity). Changes can only occur in one domain, and may also cause changes to other domains through a process of reflection and enaction [3].

\subsection{Characteristics of Effective Professional Learning Communities}

As Reference [5] notes

"An effective professional learning community (EPLC) fully exhibits eight key characteristics: shared values and vision; collective responsibility for pupils' learning; collaboration focused on learning; individual and collective professional learning; reflective professional enquiry; openness, networks and partnerships; inclusive membership; mutual trust, respect and support."

\section{Effective methods of learning in clusters are [6-7]}

a. theory explains and justifies a new practice approach. Professional development must focus on content in the context of the teacher class on ongoing curriculum and pedagogy and use effective practice models. The effective practice model should include learning plans, learning units, examples of student work, peer observation, and video or teaching case examples.

b. demonstrations provide a model of new practice for teachers how to harness learning intentions, narrative and pace.

c. practice for teachers in the classroom. Teacher practice provides space for active learning by introducing new practice in the context of their class so that it becomes highly contextual professional learning.

d. feedback on practices carried out by collaborative teams and trainers or experts. Collaborative learning can change both the culture and learning in class and school.

e. coaching for each individual about content and practical evidence helps teachers improve their new practices in the classroom.

Duration of professional development that give enough time for teachers to learn, practice, implement, and reflect on new strategies will facilitate changes in their practice [7-8].

\section{Discussion}

Professional development in Indonesia has not referred to an effective model of teacher change process. The material was not ongoing been taught to students, but based on weaknesses of the group that has been measured 
through tests. The mode of training was structured online blended and face to face that held in the learning center, all of these modes were considering based on the cluster. Structured online blended started with on service learning in online mode for several weeks which accompanied by two coaches for a group, then continued with in service learning for several weeks at the learning center. Face-to-face training is done at the learning center for several weeks. The accomplishment of the trainings were measured by online test [9].

Table 1. Data on Teacher Standardized Test: Vocational School

\begin{tabular}{|c|c|c|c|}
\hline Year & Participants & Mean of Pre-test & Mean of Post-test \\
\hline 2016 & 19,419 & 36.75 & 68.53 \\
\hline 2017 & 11,592 & 44.31 & 70.3 \\
\hline
\end{tabular}

The data above shows substantial increases in the standardized test on pedagogy and content knowledge of subject teachers in "one-shot" workshops. However, this activity did not change practice at all [6] because it was in short duration, sporadic, and not directly connected to the daily activities of teachers [8]. Observations of teacher practice in the class show teachers keep doing traditional teaching method, they find it is very hard to change the practice because of the lack of support of colleagues and mentors.

On the other hand, these mode of trainings supplied only for fraction of teachers. There are 292.212 vocational teachers in Indonesia [10], and about 8 per cent of them get professional development program in the cluster per year. Indonesia needs to provide resources for clusters as a mean of long-term and ongoing professional development.

The teacher needs time to learn and the learning cycle should be done at least within a year. Reference [11] reported "well-designed content-specific learning opportunities averaging about 50 hours over a 6 to 12 month period of time were associated with gains of up to 21 percentile points on the achievement tests used to evaluate student learning". PLC improve student learning outcomes very quickly in the countryside through a 4-year program [12], as well as dramatically improved student learning outcomes in urban areas in a 3-year program [13].

In order to be implemented, the methods must be theory, demonstrations and practice in accordance with ongoing content, feedback and coaching so that the teachers can improve their knowledge, skills and practical abilities [6]. Some activities for PLC are teacher-scholars, critical friends, school quality review, peer coaching, action research, storytelling, sharing experience, problem-solving groups, case studies practice, online PLC, online coach, etc. [14]. Effective practice models must be adapted to the content being taught to students [7-8].

The number of teachers in the cluster varies in Indonesia, which is influenced by the number of teachers in an area. There were several clusters with a very large number of members, even more than hundred teachers per cluster. On the other hand, the number of teachers was very small but in a very large area so that they join different teacher working group in some regencies in the same subjects and they only meet when there is a workshop conducted at the learning center.

Professional development must be carried out in small professional communities, in a team or network, or both [15]. Teachers must practice change and continue to work with the team to identify and eliminate the problems they face. Member of PLC could come from the same school, department, or year level [8].

\section{Conclusions}

Traditional professional development is still taking place in Indonesia. Traditional models of professional development (such as workshops, seminars, face-to-face tutorials) focus on knowledge for practice [16]. Trainers only share information on the results of research on education to teachers. The "sit and get" professional development [16] is efficient for generating information but rarely gives teacher satisfaction to professional development or produces real and meaningful changes in the classroom [7]. Thus, the knowledge gained by the teacher is actually isolated from practice [7].

Indonesian teachers participate in short-term professional development events and do not provide teachers with opportunities to participate in productive collaborative communities. Collaborative communities are the opportunities that allow teachers to work together on issues of instructional planning, learn from one another through coaching, conduct research on the outcomes of classroom practices, and collectively guide curriculum, assessment, and professional learning decisions [7].

Cluster activities should not only carried out in a short span of time and without the practical guidance from a coach in the classroom. Cluster learning methods in Indonesia still used presentations and recall skills.

Clusters should come from one school, one department, or the same grade with a range of 6-10 people [15]. Effective methods in clusters are lectures, demonstrations, practices, feedback, and coaching [6]. Cluster activities should be carried out throughout the school year with the guidance of coach on an effective learning model that is in line with teacher daily activities.

\section{Acknowledgments}

We are very grateful to all people who have contributed to this paper. 


\section{REFERENCES}

[1] World Bank. 2010. Transforming Indonesia's Teaching Force. Volume II: From Pre-service Training to Retirement: Producing and Maintaining a High-quality, Efficient, and Motivated Workforce. Jakarta: World Bank.

[2] Muralidharal, K., Pradhan M., Ree J. d., \& Rogers, H. (2016). Double for Nothing? Experimental Evidence on the Impact of an Unconditional Teacher Salary Increase on Student Performance in Indonesia," World Bank: Working Paper.

[3] Clarke, D., \& Hollingsworth, H. (2002). Elaborating a model of teacher professional growth. Teaching and Teacher Education, 18, 947-967.

[4] Guskey, T. R. (2002). Professional development and teacher change. Teachers and Teaching, 8, 381-391.

[5] Bolam, McMahon, Stoll, Thomas, \& Wallace (2005) Bolam, R., McMahon, A., Stoll, L., Thomas, S., \& Wallace, M. (2005). Creating and sustaining professional learning communities. Research Report Number 637. London, England: General Teaching Council for England, Department for Education and Skills.

[6] Joyce, B. \& Showers, B. (1980). Improving inservice training: the messages of research. Educational Leadership, 37, 379-385.

[7] Darling-Hammond, L., Hyler, M. E., \& Gardner, M. (2017). Effective Teacher Professional Development. Palo Alto, CA: Learning Policy Institute.

[8] Opfer, V., \& Pedder, D. (2011). Conceptualizing teacher professional learning. Review of Educational Research, 81(3), 376-407.

[9] Ministry of Education and Culture, (2016). Guidelines for Competency Improvement Programs. Jakarta: Directorate General Teacher and Education Personnel.

[10] Ministry of Education and Culture, (2017). Statistics of Vocational School. Jakarta: Directorate General Teacher and Education Personnel.

[11] Darling-Hammond, L., Wei, R. C., \& Andree, A., (2010). How high-achieving countries develop great teachers. Stanford, CA. Stanford Center for Opportunity Policy in Education.

[12] Berry, B., Johnson, D., \& Montgomery, D. (2005). The power of teacher leadership. Educational Leadership, 62(5), 56.

[13] Phillips, J. (2003). Powerful learning: Creating learning communities in urban school reform. Journal of Curriculum and Supervision, 18(3), 240-258.

[14] Lieberman, A. (1993). Practices that Support Teacher Development: Transforming Conceptions of Professional Learning. Phi Delta Kappan, 76 (8), 591-596.

[15] Darling-Hammond, L., Wei, R., Andree, A., Richardson, N., \& Orphanos, S. (February, 2009). Professional learning in the learning profession: A status report on teacher development in the United States and abroad. National Staff Development Council. Retrieved November 23, 2011, from. http://www.nsdc.org/news/NSDCstudy2009.pdf.
[16] Cochran-Smith, M., \& Lytle, S. (1999). Relationships of knowledge and practice: Teacher learning in communities. Review of Research in Education, 24, 249-305.

[17] McLeskey, J., \& Waldron, N. L. (2002). Professional development and inclusive schools: Reflections on effective practice. The Teacher Educator, 37(3), 159-172.

[18] Giles,C. \& Hargreaves, A. (2006). 'The sustainability of innovative schools as learning organizations and professional learning communities during standardized reform', Educational Administration Quarterly, 42, 124-156.

[19] Rich, P., \& Hannafin, M. J. (2009). Video annotation tools: Technologies to scaffold, structure, and transform teacher reflection. Journal of Teacher Education, 60(1), 52e67. doi: $10.1177 / 002248710832848$. 